\title{
Appendiceal Gastrointestinal Stromal Tumors in Adults Mini-Review of a Rare Clinical Entity
}

\author{
Kofina Konstantinia*, Ioannidis Aristeidis, Grigoriou Marios and Efthimiadis Christoforos \\ Department of Surgery, Euromedica General Clinic, Greece
}

Submission: January 30, 2017; Published: February 07, 2017

"Corresponding author: Kofina Konstantinia, MSc (Bioethics), Resident of General Surgery, Dialetti 21, 54621, Thessaloniki, Greece, Tel: 00306984383190; Email: nadiakofina@yahoo.com

Abstract

Gastrointestinal stromal tumors are extremely rarely located in the appendix and only a few cases have been described in the literature to date. Herein, we present a review of these case reports, focusing on epidemiology, clinical presentation of the condition, treatment, immunohistochemical characteristics, and other specific features.

Keywords: Appendix; Gastrointestinal stromal tumor; Appendiceal GIST

Abbreviations: GISTs: Gastrointestinal Stromal Tumors; NS: Not Specified; M: Male; F: Female; HPF: High Power Fields

\section{Introduction}

Gastrointestinal stromal tumors (GISTs) are rare mesenchymal tumors of the gastrointestinal track that express the phenotype of the interstitial cells of Cajal and are commonly associated with mutations of the tyrosine kinase receptors c-KIT [1]. They mainly occur in the stomach $(60 \%)$ and the small intestine (30\%) [2]; other rare locations include the esophagus, colon, rectum $(<5 \%$ of cases [3]), and extra gastrointestinal areas [4].

However, presence of this tumor in the appendix is considered ever rarer; in fact, only a few cases of this entity have been reported. Herein, a review of these cases is carried out, aiming to define the main characteristics of appendiceal GISTs.

\section{Results and Discussion}

Thorough bibliographic research was completed, with no restriction in date or language of publication, revealing thirteen articles, which included eighteen patients in total [516]. Unfortunately, characteristics of two cases [5] could not be retrieved; main features of the remaining sixteen cases are summarized in Table 1.

Table 1: Characteristics of reported cases of appendiceal GIST.

\begin{tabular}{|c|c|c|c|c|c|}
\hline Author & Year & Sex & Age & Symptoms & Autopsy Hpf \\
\hline Miettinen et al. [2] & 2001 & M & 64 & Symptoms of acute appendicitis & $<1$ \\
\hline Miettinen et al. [2] & 2001 & M & 56 & Incidental, during gastric GIST resection & $<1$ \\
\hline Miettinen et al. [2] & 2001 & M & 59 & Acute appendicitis & $<1$ \\
\hline Miettinen et al. [2] & 2001 & M & 72 & Symptoms of acute appendicitis & NS \\
\hline Yap et al. [7] & 2005 & F & 66 & Hematochezia & $<1$ \\
\hline Kim et al. [8] & 2007 & M & 56 & Symptoms of acute appendicitis & $<1$ \\
\hline Agaimy et al. [9] & 2008 & F & 78 & Incidental, on bladder carcinoma follow-up & $<1$ \\
\hline Agaimy et al. [9] & 2008 & M & 72 & Coexisting with mantle cell lymphoma & $<5$ \\
\hline Rahimi et al. [10] & 2008 & F & 65 & & $<$ \\
\hline
\end{tabular}




\section{Advanced Research in Gastroenterology \& Hepatology}

\begin{tabular}{|c|c|c|c|c|c|}
\hline Elazary et al. [11] & 2010 & F & 65 & Periappendiceal abscess & 9 \\
\hline Chung et al. [12] & 2012 & M & 67 & Symptoms of acute appendicitis & $<5$ \\
\hline Vassos et al. [13] & 2013 & M & 48 & Symptoms of acute appendicitis & NS \\
\hline Bouassida et al. [14] & 2013 & M & 75 & Acute appendiceal peritonitis & NS \\
\hline Ahmed et al. [15] & 2014 & F & 52 & Incidental, history of diverticulosis & $<1$ \\
\hline Back et al. [16] & 2015 & F & 88 & Symptoms of acute appendicitis & $<1$ \\
\hline Chun et al. [17] & 2016 & M & 68 & & \\
\hline
\end{tabular}

NS: Not Specified; M: Male; F: Female; HPF: High Power Fields.

Appendiceal GIST was diagnosed in ten men and six women, with a mean age of 65.7 years and range 48-88 years (mean age for men: 63.7 years, mean age for women: 69 years). In many cases the initial presentation was a clinical condition mimicking acute appendicitis $[6,7,9,12,13,17]$, or was indeed acute appendicitis $[6,14]$, though it can also be an incidental finding $[6,9]$ or show with an uncommon presentation, as hematochezia [8].

Appendiceal GISTs tend to be small-sized, benign tumors that present limited growth potential [9]. Diagnosis is mainly done postoperatively, during pathologic examination of the excised specimens, which reveals characteristic spindle cell tumors with low mitotic activity $(<1 / 50$ high power fields) in the majority of cases. Immunohistochemistry showed positivity on CD117 in nine cases $[6,9,10,12,13]$; CD34 was positive in eight cases $[6,8,9,13,14,17]$; negativity was shown on SMA, desmin and S-100 $[6,8,14,17]$, with an exception of S-100 positivity in one case [10].

Preoperative differential diagnosis was difficult, as the tumor presented with vague and non-specific symptoms. In terms of differential diagnosis of appendiceal mesenchymal tumors, surgeons should be aware that the latest are rare entities mainly represented by leiomyoma, but they can also include leiomyosarcoma, Kaposi sarcoma, granular cell tumor, schwannoma, GIST and other rare tumors [18]. Additionally, although GISTs are the most frequent mesenchymal tumors of the gastrointestinal track, presence in the appendix is surprisingly uncommon.

In cases where the tumor is characterized as low risk, no additional treatment is considered necessary, other than appendectomy [17]. In fact, all cases were treated with appendectomy, except for one case, co-existing with mantle cell lymphoma, that was treated with right hemicolectomy [10]. As the majority of cases is considered as low risk for malignancy, with a limited number of mitoses, adjuvant therapy is not usually recommended; only one case was proved malignant [11], therefore adjuvant therapy with imatinib mesylate was started. Moreover, in another case, intraoperative tumor rupture demanded further treatment with adjuvant therapy with imatinib mesylate, as it was considered as a high-risk tumor [13].

In most cases, follow-up is relatively short (approximately after two years postoperatively), though with disease-free results; in two cases, patients died after several years, but due to causes unrelated to the initial diagnosis of appendiceal GIST [6].

\section{Conclusion}

Gastrointestinal stromal tumors of the appendix are a rare, but remarkable entity, with unique characteristics, that often mimics the symptoms of acute appendicitis or presents non-specific symptoms. Treatment should be individualized according to the specific findings in every patient. Long-term follow-up examination is important in order to confirm the behavior of this uncommon tumor.

\section{Conflict of Interest}

No financial support was received for the preparation of this study. The authors declare that no conflict of interest exists.

\section{References}

1. Tirumani SH, Baheti AD, Tirumani H, O'Neill A, Jagannathan JP (2017) Update on gastrointestinal stromal tumars for radiologists. Korean J Radiol 18(1): 84-93.

2. Miettinen M, Lasota J (2006) Gastrointestinal stromal tumours: pathology and prognosis at different sites. Semin Diagn Pathol 23(2): 70-83

3. Tazawa H, Hirata Y, Kuga Y, Nishida T, Sakimoto H (2017) Sphinctersaving resection by cluneal arched skin incision for a gastrointestinal stromal tumor (GIST) of the lower rectum: a case report. Surg Case Rep 3(1): 8 .

4. Saeed Z, Taleb S, Evans-Molina C (2016) A case of extragastrointestinal stromal tumor complicated by severe hypoglycemia: a unique presentation of a rare tumor. BMC Cancer 16(1): 930.

5. Sturm E, Stupart D, Standish A (2016) The rarely spotted appendiceal GIST: two Australian cases. Journal of Gastroenterology and Hepatology 31: 61 .

6. Miettinen M, Sobin LH (2001) Gastrointestinal stromal tumors in the appendix: a clinicopathologic and immunohistochemical study of four cases. Am J Surg Pathol 25(11): 1433-1437.

7. Yap WM, Tan HW, Goh SG, Chuah K (2005) Appendiceal gastrointestinal stromal tumor. Am J Surg Pathol 29: 1545-1547.

8. Kim KJ, Moon W, Park MI, Park SJ, Lee SH, et al. (2007) Gastrointestinal stromal tumor of appendix incidentally diagnosed by appendiceal hemorrhage. World J Gastroenterol 13(23): 3265-3267.

9. Agaimy A, Pelz AF, Wieacker P, Roessner A, Wunsch PH, et al. (2008) Gastrointestinal stromal tumors of the vermiform appendix: clinicopathologic, immunohistochemical, and molecular study of 2 cases with literature review. Hum Pathol 39(8): 1252-1257. 
10. Rahimi K, Gologan A, Haliotis T, Lamoureux E, Chetty R (2008) Gastrointestinal stromal tumor with autonomic nerve differentiation and coexistent mantle cell lymphoma involving the appendix Int J Clin Exp Pathol 2(6): 608-613.

11. Elazary R, Schlager A, Khalaileh A, Appelbaum L, Bala M, et al. (2010) Malignant appendiceal GIST: case report and review of the literature Gastrointest Cancer 41(1): 9-12.

12. Chung JC, Song OP (2012) Gastrointestinal stromal tumor of the appendix Turk J Gastroenterol 23: 303-304.

13. Vassos N, Agaimy A, Gunther K, Hohenberger W, Schneider-Stock R, et al. (2013) A novel complex KIT mutation in a gastrointestinal stromal tumor of the vermiform appendix Hum Pathol 44(4): 651-655.

14. Bouassida M, Chtourou MF, Chalbi E, Chebbi F, Hamzaoui L, et al. (2013) Appendiceal GIST: report of an exceptional case and review of the literature Pan Afr Med J 15: 85.
15. Ahmed S, Abubakar M, Mohammed U, Mayun A (2014) Gastrointestinal stromal tumor of the appendix Oncology Gastroenterology and Hepatology Reports 3(2): 38-40.

16. Back J, Jeanty J, Landas S (2015) Gastrointestinal stromal tumor of the appendix: case report and review of the literature Hum Pathol Case Rep 2(4): 94-98.

17. Chun JM, Lim KH (2016) Gastrointestinal stromal tumor of the vermiform appendix mimicking Meckel's diverticulum: case report with literature review Int J Surg Case Rep 21: 20-22.

18. Misdraji J, Graeme-Cook FM (2004) Miscellaneous conditions of the appendix Semin Diagn Pathol 21(2): 151-163.

\section{Your next submission with Juniper Publishers will reach you the below assets}

- Quality Editorial service

- Swift Peer Review

- Reprints availability

- E-prints Service

- Manuscript Podcast for convenient understanding

- Global attainment for your research

- Manuscript accessibility in different formats

( Pdf, E-pub, Full Text, Audio)

- Unceasing customer service

Track the below URL for one-step submission https://juniperpublishers.com/online-submission.php 